\title{
Methanolinea mesophila sp. nov., a hydrogenotrophic methanogen isolated from rice field soil, and proposal of the archaeal family Methanoregulaceae fam. nov. within the order Methanomicrobiales
}

\author{
Correspondence \\ Sanae Sakai \\ sakai-s@jamstec.go.jp
}

\author{
Sanae Sakai, ${ }^{1}$ Masayuki Ehara, ${ }^{1,2}$ I-Cheng Tseng, ${ }^{3}$ Takashi Yamaguchi, ${ }^{2}$ \\ Suzanna L. Bräuer, ${ }^{4}$ Hinsby Cadillo-Quiroz, ${ }^{5}$ Stephen H. Zinder ${ }^{6}$ \\ and Hiroyuki Imachi ${ }^{1}$
}
${ }^{1}$ Subsurface Geobiology Advanced Research (SUGAR) Project, Extremobiosphere Research Program, Institute of Biogeosciences, Japan Agency for Marine-Earth Science \& Technology (JAMSTEC), Yokosuka, Kanagawa 237-0061, Japan
${ }^{2}$ Department of Environmental Systems Engineering, Nagaoka University of Technology, Nagaoka, Niigata 940-2188, Japan
${ }^{3}$ Department of Biology, National Cheng Kung University, Tainan 701, Taiwan, ROC
${ }^{4}$ Department of Biology, Appalachian State University, Boone, NC 28608, USA
${ }^{5}$ School of Life Sciences, Arizona State University, Tempe, AZ 85287, USA
${ }^{6}$ Department of Microbiology, Cornell University, Ithaca, NY 14853, USA

\begin{abstract}
A novel mesophilic, hydrogenotrophic methanogen, designated strain $\mathrm{TNR}^{\top}$, was isolated from an anaerobic, propionate-degradation enrichment culture that was originally established from a rice field soil sample from Taiwan. Cells were non-motile rods, $2.0-6.5 \mu \mathrm{m}$ long by $0.3 \mu \mathrm{m}$ wide. Filamentous (up to about $100 \mu \mathrm{m}$ ) and coccoid (about $1 \mu \mathrm{m}$ in diameter) cells were also observed in cultures in the late exponential phase of growth. Strain TNR grew at $20-40{ }^{\circ} \mathrm{C}$ (optimally at $37{ }^{\circ} \mathrm{C}$ ), at pH 6.5-7.4 (optimally at $\mathrm{pH} 7.0$ ) and in the presence of $0-25 \mathrm{~g} \mathrm{NaCl}^{-1}$ (optimally at $0 \mathrm{~g} \mathrm{NaCl} \mathrm{I}^{-1}$ ). The strain utilized $\mathrm{H}_{2} / \mathrm{CO}_{2}$ and formate for growth and produced methane. The $\mathrm{G}+\mathrm{C}$ content of the genomic DNA was 56.4 mol\%. Based on sequences of both the 16S rRNA gene and the methanogen-specific marker gene $\mathrm{mcr} A$, strain $\mathrm{TNR}^{\top}$ was related most closely to Methanolinea tarda $\mathrm{NOBI}-1^{\top}$; levels of sequence similarities were 94.8 and $86.4 \%$, respectively. The $16 \mathrm{~S}$ rRNA gene sequence similarity indicates that strain $\mathrm{TNR}^{\top}$ and $M$. $\operatorname{tarda} \mathrm{NOBI}-1^{\top}$ represent different species within the same genus. This is supported by shared phenotypic properties, including substrate usage and cell morphology, and differences in growth temperature. Based on these genetic and phenotypic properties, strain TNR ${ }^{\top}$ is considered to represent a novel species of the genus Methanolinea, for which the name Methanolinea mesophila sp. nov. is proposed; the type strain is $\mathrm{TNR}^{\top}$ (=NBRC $105659^{\top}=\mathrm{DSM} 23604^{\top}$ ). In addition, we also suggest family status for the E1/E2 group within the order Methanomicrobiales, for which the name Methanoregulaceae fam. nov. is proposed; the type genus of family is Methanoregula.
\end{abstract}

The genus Methanolinea, belonging to the order Methanomicrobiales, was described as an $\mathrm{H}_{2} / \mathrm{CO}_{2}$-using methanogenic

Abbreviation: FISH, fluorescence in situ hybridization.

The GenBank/EMBL/DDBJ accession numbers for the 16S rRNA and mcrA gene sequences of strain $\operatorname{TNR}^{\top}$ are AB447467 and AB496719, respectively.

Two supplementary figures are available with the online version of this paper. archaeon (Imachi et al., 2008). The genus currently consists of only one species, Methanolinea tarda, the type strain of which, NOBI- $1^{\mathrm{T}}$, was isolated from a methanogenic sludge treating municipal sewage sludge (Imachi et al., 2008). Moreover, several 16S rRNA gene surveys have retrieved Methanolinearelated clones from a variety of anaerobic environments, including methanogenic sludge (Chen et al., 2004, 2009; Díaz et al., 2006; Imachi et al., 2008; Lykidis et al., 2011; Narihiro et al., 2009; Sakai et al., 2009; Yashiro et al., 2011), marine 
sediment (Sakai et al., 2009), fen sediment (Cadillo-Quiroz et al., 2008) and lake sediment (Sakai et al., 2009; Ye et al., 2009), indicating the widespread distribution of Methanolinealike methanogens.

We previously reported the isolation of a novel methanogen, designated strain $\mathrm{TNR}^{\mathrm{T}}$, from rice field soil in Taiwan (Sakai et al., 2009). 16S rRNA gene sequence analysis revealed that the strain has $94.8 \% 16 \mathrm{~S}$ rRNA gene sequence similarity with Methanolinea tarda NOBI- $1^{\mathrm{T}}$, suggesting that strain $\mathrm{TNR}^{\mathrm{T}}$ might be a member of the genus Methanolinea. In this report, we describe detailed morphological and physiological characteristics and genetic features of strain $\mathrm{TNR}^{\mathrm{T}}$ and propose the strain as a representative of a novel species of the genus Methanolinea. In addition, we propose a new family within the order Methanomicrobiales. In recent years, the names of three novel genera within the order Methanomicrobiales have been validly published: the genera Methanolinea (Imachi et al., 2008), Methanosphaerula (CadilloQuiroz et al., 2009) and Methanoregula (Bräuer et al., 2011; Yashiro et al., 2011). All those species belong to the family-level clade called the E1/E2 group or Fen Cluster that has long been recognized as an uncultured archaeal group (Bräuer et al., 2006b; Cadillo-Quiroz et al., 2006; Galand et al., 2002; Hales et al., 1996). The 16S rRNA gene based phylogenetic analysis indicates that this clade is distinct from the other families among the order Methanomicrobiales. Therefore, we also propose the family Methanoregulaceae fam. nov., with Methanoregula (Bräuer et al., 2011) as the type genus of this new family.

Strain $\mathrm{TNR}^{\mathrm{T}}$ was isolated from an anaerobic, propionatedegrading enrichment culture that was originally obtained from rice field soil of Tainan, Taiwan (Sakai et al., 2009). To obtain the strain in pure culture, we used serial dilution into both liquid and solid media supplemented with $\mathrm{H}_{2} /$ $\mathrm{CO}_{2}(80 / 20, \mathrm{v} / \mathrm{v}$; approx. $150 \mathrm{kPa}$ in the head space) or formate $(40 \mathrm{mM})$, using the propionate enrichment as the inoculum. Acetate $(1 \mathrm{mM})$, yeast extract $(0.01 \%$, w/v; Difco), vancomycin and ampicillin $\left(50 \mu \mathrm{g} \mathrm{ml}^{-1}\right.$ each) were also added to the cultures. As a result, we obtained a pure culture of strain $\mathrm{TNR}^{\mathrm{T}}$ in liquid medium supplemented with $\mathrm{H}_{2} / \mathrm{CO}_{2}$. The purity of strain $\mathrm{TNR}^{\mathrm{T}}$ was confirmed as previously described (Sakai et al., 2007), with the exception that the 16S rRNA-targeted oligonucleotide probe TNR625 (5'-TATCCCCCGGACGCCCAT-3'; positions $125-142$ in Escherichia coli) for strain $\mathrm{TNR}^{\mathrm{T}}$ was used for fluorescence in situ hybridization (FISH) analysis. The oligonucleotide probe was designed by using the ARB program (Ludwig et al., 2004) and was labelled with Cy3. The stringency of hybridization of the probe was adjusted by adding formamide to the hybridization buffer $(35 \%, \mathrm{v} / \mathrm{v})$. The specificity of the oligonucleotide probe TNR625 was estimated using a pure culture of Halogeometricum borinquense ATCC $700274^{\mathrm{T}}$ $\left(=\mathrm{JCM} 10706^{\mathrm{T}}\right)$, which contained two mismatches in the probe target site. Non-specific hybridization of probe TNR625 to $H$. borinquense cells was observed under the hybridization conditions mentioned above.
The basal medium was prepared as previously described (Imachi et al., 2009). The medium consisted of the following components (per litre distilled water): $0.54 \mathrm{~g} \mathrm{NH}_{4} \mathrm{Cl}, 0.14 \mathrm{~g}$ $\mathrm{KH}_{2} \mathrm{PO}_{4}, 0.2 \mathrm{~g} \mathrm{MgCl}_{2} .6 \mathrm{H}_{2} \mathrm{O}, 0.15 \mathrm{~g} \mathrm{CaCl}_{2} .2 \mathrm{H}_{2} \mathrm{O}, 2.5 \mathrm{~g}$ $\mathrm{NaHCO}_{3}, 0.3 \mathrm{~g} \mathrm{Na}_{2} \mathrm{~S} .9 \mathrm{H}_{2} \mathrm{O}, 0.3 \mathrm{~g}$ cysteine- $\mathrm{HCl}, 1 \mathrm{ml}$ trace element solution, $1 \mathrm{ml}$ vitamin solution and $1 \mathrm{ml}$ resazurin solution $\left(1 \mathrm{mg} \mathrm{ml}^{-1}\right)$. The trace element solution contained (per litre distilled water): $1.27 \mathrm{~g} \mathrm{FeCl}_{2}, 0.13 \mathrm{~g} \mathrm{CoCl}_{2}, 0.2 \mathrm{~g}$ $\mathrm{MnCl}_{2} .4 \mathrm{H}_{2} \mathrm{O}, 0.14 \mathrm{~g} \mathrm{ZnCl}_{2}, 0.006 \mathrm{~g} \mathrm{H}_{3} \mathrm{BO}_{3}, 0.01 \mathrm{~g} \mathrm{NiCl}_{2}$, $0.01 \mathrm{~g} \mathrm{AlCl}_{3}, 0.02 \mathrm{~g} \mathrm{Na}_{2} \mathrm{MoO}_{4} .2 \mathrm{H}_{2} \mathrm{O}, 0.002 \mathrm{~g} \mathrm{Na}_{2} \mathrm{SeO}_{3}$, $0.003 \mathrm{~g} \mathrm{Na}_{2} \mathrm{WO}_{4} \cdot \mathrm{H}_{2} \mathrm{O}$ and $0.001 \mathrm{~g} \mathrm{CuCl}_{2}$. The vitamin solution was composed of the following vitamins (per litre distilled water): $4.9 \mathrm{mg}$ biotin, $2.7 \mathrm{mg} p$-aminobenzoic acid, $9.5 \mathrm{mg}$ D-pantothenate (calcium salt), $4.1 \mathrm{mg}$ pyridoxine. $\mathrm{HCl}, 2.4 \mathrm{mg}$ nicotinic acid, $6.7 \mathrm{mg}$ thiamine. $\mathrm{HCl}, 4.1 \mathrm{mg}$ lipoic acid, $8.8 \mathrm{mg}$ folic acid, $27.1 \mathrm{mg}$ vitamin $\mathrm{B}_{12}$ and $7.5 \mathrm{mg}$ riboflavin. The standard medium normally contained both $1 \mathrm{mM}$ acetate and $0.01 \%(\mathrm{w} / \mathrm{v})$ yeast extract. However, those compounds were not added into the medium when growth requirement tests were performed. The cultivations were performed anaerobically at $37^{\circ} \mathrm{C}$ under an atmosphere of $\mathrm{H}_{2} / \mathrm{CO}_{2}(80: 20, \mathrm{v} / \mathrm{v})$ or $\mathrm{N}_{2} / \mathrm{CO}_{2}$ $(80: 20, v / v)$ without shaking. Growth and substrate utilization were determined by monitoring the concentration of methane with a 3200G GC (GL Science) using a thermal conductivity detector. Tests for growth temperature, $\mathrm{pH}$ and

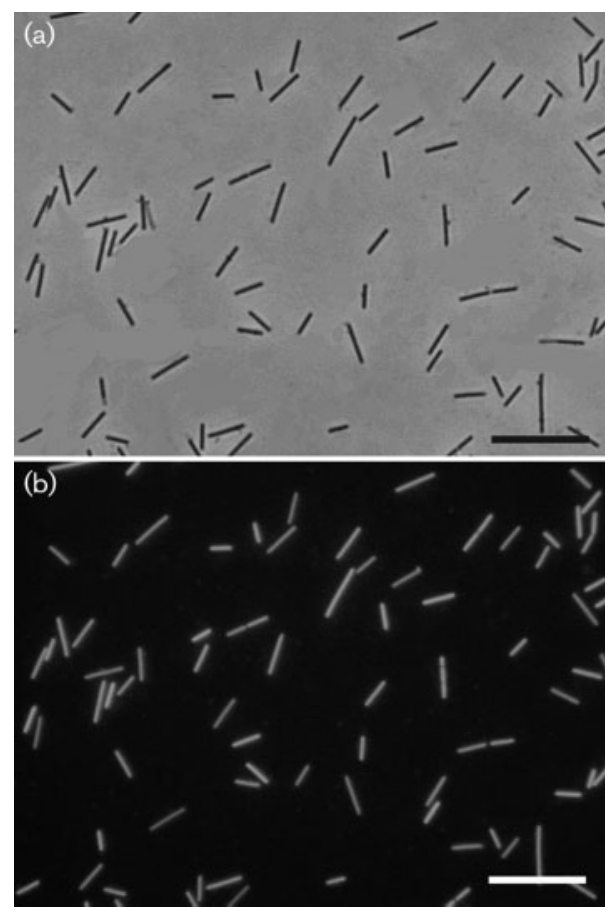

Fig. 1. Photomicrographs of strain $T N^{\top}$ grown on $\mathrm{H}_{2} / \mathrm{CO}_{2}$ (approx. $150 \mathrm{kPa}$ in the headspace) medium supplemented with acetate $(1 \mathrm{mM})$ and yeast extract $(0.01 \%, \mathrm{w} / \mathrm{v})$. (a) Phase-contrast and (b) fluorescence micrographs indicating the presence of high levels of coenzyme $F_{420}$ in identical fields. Bars, $10 \mu \mathrm{m}$. 


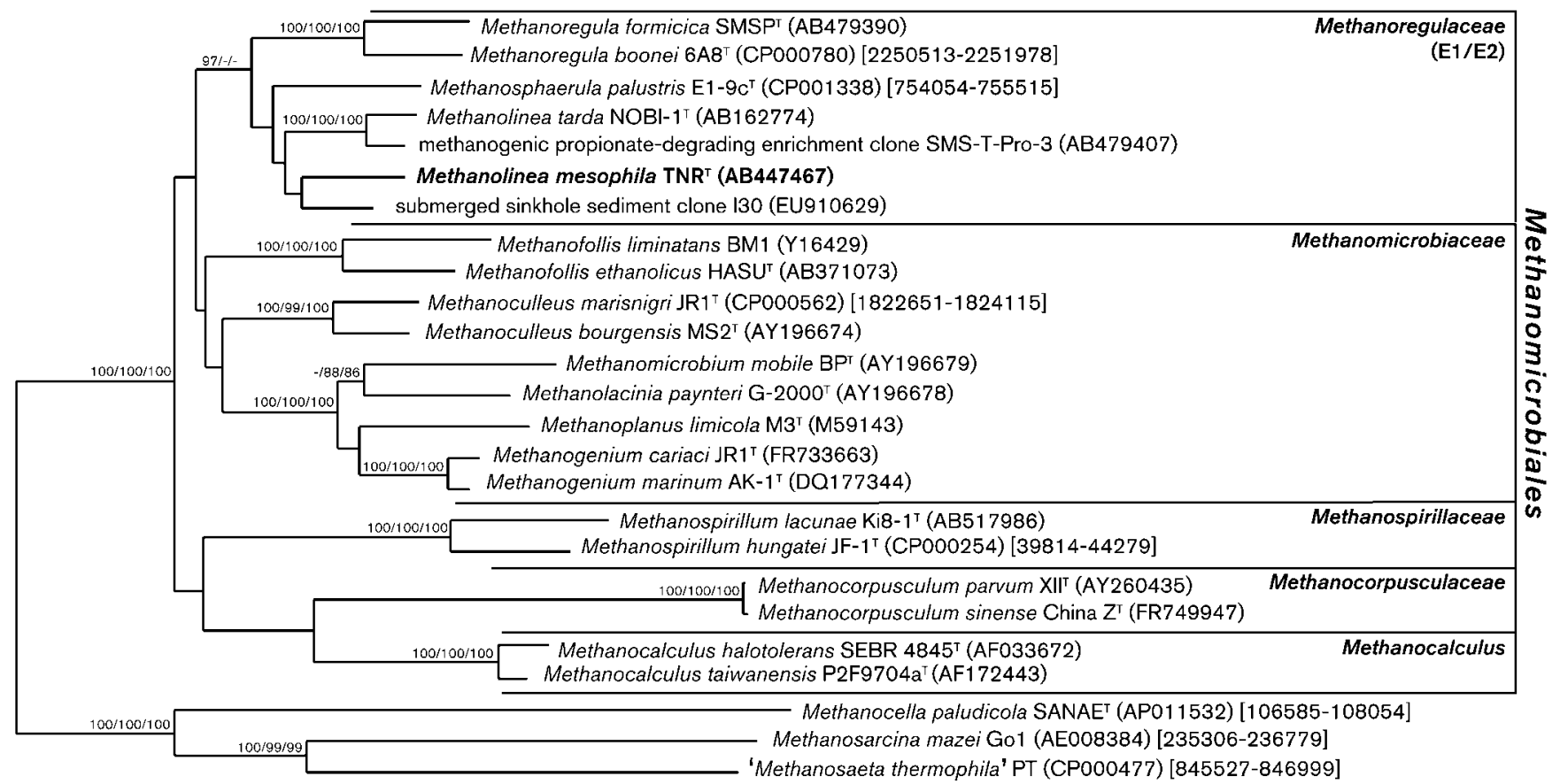

0.10

Fig. 2. Phylogenetic tree of the order Methanomicrobiales based on comparative analyses of $16 \mathrm{~S}$ rRNA gene sequences, showing the placement of strain TNR ${ }^{\top}$. The tree was calculated on a subset of 25 nearly full-length $16 \mathrm{~S}$ rRNA gene sequences by neighbour-joining analysis in combination with filters, which considered at least $50 \%$ conserved regions of the $16 \mathrm{~S}$ rRNA sequences to exclude the influence of highly variable positions. For sequences taken from complete genomic sequences, their position on the genome is indicated in brackets. Bootstrap values were obtained from the neighbour-joining/maximum-parsimony/ maximum-likelihood methods based on 1000 replicates;,$-<50 \%$. Bar, 0.10 changes per nucleotide sequence position.

salinity range were carried out at $10-60{ }^{\circ} \mathrm{C}, \mathrm{pH} 5.0-8.0$ and 0 $30 \mathrm{~g} \mathrm{NaCl}^{-1}$. The $\mathrm{pH}$ was adjusted at room temperature by adding filter-sterilized $\mathrm{HCl}$ or $\mathrm{NaOH}$ solution. The medium was routinely monitored with a portable $\mathrm{pH}$ meter (HORIBA Twin $\mathrm{pH} \mathrm{B-212)} \mathrm{to} \mathrm{determine} \mathrm{whether} \mathrm{the} \mathrm{initial} \mathrm{pH}$ conditions had changed during incubation; the $\mathrm{pH}$ was readjusted with $\mathrm{HCl}$ or $\mathrm{NaOH}$ when the initial $\mathrm{pH}$ changed significantly. Salinity tests were performed using the same medium described above (which already contains $33 \mathrm{mM} \mathrm{Na}^{+}$ and $14 \mathrm{mM} \mathrm{Cl}^{-}$). Antibiotic susceptibility was evaluated by using cultures supplemented with antibiotics at final concentrations of $100 \mu \mathrm{g} \mathrm{ml}^{-1}$. All measurements were performed in triplicate and all incubations were terminated after 3 months.

Cell morphology and motility were examined by phasecontrast microscopy (Olympus BX51F) with a colour CCD camera (Olympus DP71). Susceptibility to lysis was examined by adding SDS to final concentrations of $0.01-$ $2.0 \%(\mathrm{w} / \mathrm{v})$ and cell lysis was determined by microscopic observation of cell integrity. The $\mathrm{G}+\mathrm{C}$ content of the genomic DNA was determined by HPLC as described by Nakagawa et al. (2003). The procedures used for DNA extraction, PCR amplification, cloning and sequencing were as reported elsewhere (Imachi et al., 2006; Sakai et al., 2008). Sequence similarity values were calculated by using the
Calculate Matrix function of the ARB program. A phylogenetic tree based on $16 \mathrm{~S}$ rRNA gene sequences was constructed by using the neighbour-joining method in the ARB program package. To estimate the confidence of the tree topologies, bootstrap resampling analysis (Felsenstein, 1985) with 1000 replicates was performed for the neighbour-joining, maximum-parsimony and maximum-likelihood methods by using MEGA5 software (Tamura et al., 2011).

Cells of strain $\mathrm{TNR}^{\mathrm{T}}$ were non-motile, rod-shaped, 2.0$6.5 \mu \mathrm{m}$ long and $0.3 \mu \mathrm{m}$ wide (Fig. 1). Particularly in lateexponential phase cultures, cultures formed multicellular filaments with lengths of about $>100 \mu \mathrm{m}$ and coccoid cells (about $1 \mu \mathrm{m}$ diameter). FISH analysis using the strainspecific probe TNR625 identified both cell morphologies as belonging to strain $\mathrm{TNR}^{\mathrm{T}}$ (Fig. S1, available in IJSEM Online). The cells autofluoresced under epifluorescence microscopy when excited with light near $420 \mathrm{~nm}$ in wavelength (Fig. 1). This indicated the presence of high levels of coenzyme $\mathrm{F}_{420}$, which is diagnostic for methanogens. The cells resisted disruption in less than $0.1 \%(w / v)$ SDS.

$\mathrm{H}_{2} / \mathrm{CO}_{2}$ and formate $(40 \mathrm{mM}$ ) supported growth and methane production by $\mathrm{TNR}^{\mathrm{T}}$. The following substrates did not support growth and/or methane production: acetate $(20 \mathrm{mM})$, 
Table 1. Comparison of morphological and physiological characteristics of strain $\operatorname{TNR}^{\top}$, species within the new family Methanoregulaceae and type species of genera within the order Methanomicrobiales

Strains: 1, strain TNR ${ }^{\mathrm{T}}$ (data from this study); 2, Methanolinea tarda NOBI-1 ${ }^{\mathrm{T}}$ (data from Imachi et al., 2008); 3, Methanoregula boonei 6A8 $8^{\mathrm{T}}$ (Bräuer et al., 2006a, 2011); 4, Methanoregula formicica $\mathrm{SMSP}^{\mathrm{T}}$ (Yashiro et al., 2011); 5, Methanosphaerula palustris $\mathrm{E1}-9 \mathrm{c}^{\mathrm{T}}$ (Cadillo-Quiroz et al., 2009); 6, Methanomicrobium mobile $\mathrm{BP}^{\mathrm{T}}$ (Paynter \& Hungate, 1968); 7, Methanoculleus bourgensis $\mathrm{MS2}^{\mathrm{T}}$ (Ollivier et al., 1986); 8, Methanofollis tationis Chile $9^{\mathrm{T}}$ (Zabel et al., 1984); 9, Methanogenium cariaci JR1 ${ }^{\mathrm{T}}$ (Romesser et al., 1979); 10, Methanolacinia paynteri G-2000 ${ }^{\mathrm{T}}$ (Rivard et al., 1983); 11, Methanoplanus limicola $\mathrm{M}^{\mathrm{T}}$ (Wildgruber et al., 1982); 12, Methanospirillum hungatei JF-1 ${ }^{\mathrm{T}}$ (Ferry et al., 1974); 13, Methanocorpusculum parvum XII ${ }^{\mathrm{T}}$ (Zellner et al., 1987); 14, Methanocalculus halotolerans SEBR $4845^{\mathrm{T}}$ (Ollivier et al., 1998). -, Negative; +, positive; \pm , species-dependent; NR, not reported.

\begin{tabular}{|c|c|c|c|c|c|c|c|c|c|c|c|c|c|c|}
\hline \multirow[t]{2}{*}{ Characteristic } & \multicolumn{5}{|c|}{ Methanoregulaceae } & \multicolumn{6}{|c|}{ Methanomicrobiaceae } & \multirow{2}{*}{$\begin{array}{c}\begin{array}{c}\text { Methano- } \\
\text { spirillaceae }\end{array} \\
12\end{array}$} & \multirow{2}{*}{$\begin{array}{c}\begin{array}{c}\text { Methano- } \\
\text { corpusculaceae }\end{array} \\
13\end{array}$} & \multirow{2}{*}{$\begin{array}{l}\text { Unassigned } \\
14\end{array}$} \\
\hline & 1 & 2 & 3 & 4 & 5 & 6 & 7 & 8 & 9 & 10 & 11 & & & \\
\hline $\begin{array}{l}\text { Cell } \\
\text { morphology }\end{array}$ & Rods $^{*}$ & Rods $\dagger$ & $\begin{array}{c}\text { Rods and } \\
\text { irregular } \\
\text { coccoid }\end{array}$ & Rods $\ddagger$ & Coccoid & $\begin{array}{l}\text { Curved } \\
\text { rod }\end{array}$ & $\begin{array}{r}\text { Irregular } \\
\text { coccoid }\end{array}$ & $\begin{array}{r}\text { Irregular } \\
\text { coccoid }\end{array}$ & $\begin{array}{r}\text { Irregular } \\
\text { coccoid }\end{array}$ & $\begin{array}{l}\text { Irregular } \\
\text { rod }\end{array}$ & $\begin{array}{l}\text { Plate- } \\
\text { shaped }\end{array}$ & $\begin{array}{l}\text { Curved } \\
\text { rod }\end{array}$ & $\begin{array}{r}\text { Irregular } \\
\text { coccoid }\end{array}$ & $\begin{array}{r}\text { Irregular } \\
\text { coccoid }\end{array}$ \\
\hline $\begin{array}{l}\text { Cell } \\
\text { width/diameter } \\
(\mu \mathrm{m})\end{array}$ & 0.3 & $0.7-1.0$ & $0.2-0.3$ & 0.5 & $0.5-0.8$ & $0.6-0.7$ & $1.0-2.0$ & $1.5-3.0$ & $>2.6$ & 0.6 & $1.6-2.8$ & $0.4-0.5$ & $>1.0$ & $0.8-1.0$ \\
\hline $\begin{array}{l}\text { Cell length } \\
(\mu \mathrm{m})\end{array}$ & $2.0-6.5$ & $2.0-8.0$ & $0.8-3.0$ & $1.0-2.6$ & & $1.5-2.0$ & & & & $1.5-2.5$ & 1.5 & $7.4-20$ & & \\
\hline Motility & - & - & - & - & - & $+($ weakly $)$ & - & \pm & - & - & $\stackrel{+}{+}$ & + (weakly) & + (weakly) & NR \\
\hline $\begin{array}{l}\text { DNA G }+ \text { C content } \\
(\mathrm{mol} \%) \S\end{array}$ & $56.4^{a}$ & $56.3^{a}$ & $54.5^{b}$ & $56.2^{a}$ & $58.9^{c}$ & $48.8^{d}$ & $59^{d}$ & $54^{c}$ & $51.6^{d}$ & $44.9^{d}$ & $47.5^{c}$ & $45^{d}$ & $48.5^{c}$ & $55^{a}$ \\
\hline \multicolumn{15}{|l|}{ Growth temperature $\left({ }^{\circ} \mathrm{C}\right)$} \\
\hline Range & $20-40$ & $35-55$ & $10-40$ & $10-40$ & $14-35$ & $30-45$ & NR & $25-45$ & $\mathrm{NR}$ & $20-45$ & $17-41$ & NR & $20-45$ & $25-45$ \\
\hline Optimum & 37 & 50 & $35-37$ & $30-33$ & 30 & 40 & 37 & $37-40$ & $20-25$ & 45 & 40 & $30-37$ & 37 & 38 \\
\hline \multicolumn{15}{|l|}{ Growth pH } \\
\hline Range & $6.5-7.4$ & $6.7-8.0$ & $4.5-5.5$ & $7.0-7.6$ & $4.8-6.4$ & $5.9-7.7$ & $5.5-8.0$ & $6.3-8.8$ & NR & $6.6-7.3$ & $\mathrm{NR}$ & NR & $6.0-8.0$ & $7.0-8.4$ \\
\hline Optimum & 7 & 7 & 5.1 & 7.4 & 5.7 & $6.1-6.9$ & 6.7 & 7 & $6.8-7.3$ & 7 & $6.5-7.5$ & $6.6-7.4$ & $6.8-7.5$ & 7.6 \\
\hline \multicolumn{15}{|l|}{ Substrate utilization } \\
\hline $\mathrm{H}_{2} / \mathrm{CO}_{2}$ & + & + & + & + & + & + & + & + & + & + & + & + & + & + \\
\hline Formate & + & + & - & + & + & + & + & + & + & - & + & + & + & + \\
\hline $\begin{array}{l}\text { Secondary } \\
\text { alcohols }\end{array}$ & - & - & - & - & - & - & - & - & - & - & - & - & + & - \\
\hline \multicolumn{15}{|l|}{$\begin{array}{l}\text { alcohols } \\
\text { Growth requirements }\end{array}$} \\
\hline Yeast extract & - & + & + & + & - & + & - & + & + & - & - & - & + & - \\
\hline Acetate & + & + & + & + & + & + & + & + & + & + & + & - & + & + \\
\hline Coenzyme M & - & -11 & + & - & + & - & NR & NR & NR & NR & NR & NR & NR & NR \\
\hline
\end{tabular}

${ }^{\star}$ Coccoid and multicellular filamentous cells were observed especially in late-exponential phase culture.

†Cells often formed multicellular filaments longer than $8 \mu \mathrm{m}$ in the syntrophic propionate-degrading enrichment culture.

¥Coccoid cells were observed in mid- to late-exponential phase culture.

$\S$ Determined by: $a$, HPLC; $b$, obtained from genome information; $c$, thermal denaturation; $d$, buoyant density.

IICoenzyme $\mathrm{M}$ was not required for growth, but supplementation with coenzyme $\mathrm{M}$ greatly improved the cell density (data from this study). 
1-propanol (5 mM), 2-propanol (5 mM), ethanol (5 mM), 1butanol (5 mM), 2-butanol (5 mM), cyclopentanol (5 mM), methanol $(20 \mathrm{mM})$, methylamine $(10 \mathrm{mM})$, dimethylamine $(10 \mathrm{mM})$, trimethylamine $(10 \mathrm{mM})$ and propionate $(20 \mathrm{mM})$. Acetate $(1 \mathrm{mM})$ was required as a carbon source for growth. Yeast extract $(0.01 \%, \mathrm{w} / \mathrm{v})$ and coenzyme $\mathrm{M}(0.5 \mathrm{mM})$ were not required but enhanced growth.

Strain $\mathrm{TNR}^{\mathrm{T}}$ grew at $20-40{ }^{\circ} \mathrm{C}$ (optimal growth at $37^{\circ} \mathrm{C}$ ), at $\mathrm{pH}$ 6.5-7.4 (optimum around $\mathrm{pH}$ 7.0) and in the presence of $0-25 \mathrm{~g} \mathrm{NaCl}^{-1}$ (optimal growth in $0 \mathrm{~g} \mathrm{NaCl} \mathrm{l}^{-1}$; growth was inhibited completely in $30 \mathrm{~g} \mathrm{NaCl} \mathrm{l}^{-1}$ ). Under optimal conditions $\left(\mathrm{pH} 7.0,37{ }^{\circ} \mathrm{C}\right.$ ), the doubling time on $\mathrm{H}_{2} / \mathrm{CO}_{2}$ medium was approximately 1.2 days, as calculated from the methane production rate. The strain tolerated ampicillin, vancomycin, kanamycin and streptomycin, but not rifampicin, tetracycline or chloramphenicol.

The DNA G $+\mathrm{C}$ content of strain $\mathrm{TNR}^{\mathrm{T}}$ was $56.4 \mathrm{~mol} \%$. 16S rRNA gene sequence based phylogenetic analysis showed that strain $\mathrm{TNR}^{\mathrm{T}}$ is affiliated with the order Methanomicrobiales (Fig. 2). The most closely related strain was Methanolinea tarda NOBI- $1^{\mathrm{T}}$ (Imachi et al., 2008), with $16 \mathrm{~S}$ rRNA and $m c r A$ gene sequence similarities of 94.8 and $86.4 \%$, respectively.

Strain $\mathrm{TNR}^{\mathrm{T}}$ and Methanolinea tarda NOBI- $1^{\mathrm{T}}$ have similar features. However, the $16 \mathrm{~S}$ rRNA gene sequence similarity $(94.8 \%)$ is in the range of species-level differences (Keswani \& Whitman, 2001; Stackebrandt \& Goebel, 1994). Thus, strain $\mathrm{TNR}^{\mathrm{T}}$ and Methanolinea tarda NOBI- $1^{\mathrm{T}}$ should be considered as members of the same genus. In addition to the 16S rRNA gene sequence similarities, they have common phenotypic properties. They are hydrogenotrophic methanogens, which can utilize $\mathrm{H}_{2} / \mathrm{CO}_{2}$ and formate as substrates. Cell morphology is also similar; both organisms are rodshaped cells, forming multicellular filaments. However, coccoid type cells were not observed for Methanolinea tarda NOBI- $1^{\mathrm{T}}$. Other differential characteristics between $\mathrm{TNR}^{\mathrm{T}}$ and Methanolinea tarda NOBI- $1^{\mathrm{T}}$ were also observed (Table 1). The temperature ranges for growth differed markedly: strain $\mathrm{TNR}^{\mathrm{T}}$ was mesophilic whereas Methanolinea tarda NOBI- $1^{\mathrm{T}}$ was thermophilic. There are also small differences in the $\mathrm{pH}$ range and growth requirements. The $\mathrm{pH}$ range for strain TNR $^{\mathrm{T}}$ was $\mathrm{pH}$ 6.5-7.4 and that for Methanolinea tarda NOBI$1^{\mathrm{T}}$ was $\mathrm{pH}$ 6.7-8.0. The supplementation of coenzyme M significantly improved growth of Methanolinea tarda NOBI$1^{\mathrm{T}}$, but a similar effect was not observed for strain $\mathrm{TNR}^{\mathrm{T}}$. On the basis of these physiological and phylogenetic properties, it is proposed that strain $\mathrm{TNR}^{\mathrm{T}}$ represents a novel species of the genus Methanolinea, Methanolinea mesophila sp. nov.

The members of the genus Methanolinea phylogenetically belong to the family level clade E1/E2 within the order Methanomicrobiales (Fig. 2; alignments of 16S rRNA genes are shown in Fig. S2). This clade also includes two other genera, Methanoregula and Methanosphaerula. The bootstrap values of the 16S rRNA gene-based phylogenetic tree solidly supported the group E1/E2 (Fig. 2). In addition, 16S rRNA gene sequence similarities among strains of species belonging to group E1/E2 (i.e. strain $\mathrm{TNR}^{\mathrm{T}}$, Methanolinea tarda NOBI$1^{\mathrm{T}}$, Methanoregula boonei $6 \mathrm{~A}^{\mathrm{T}}$, Methanoregula formicica $\mathrm{SMSP}^{\mathrm{T}}$ and Methanosphaerula palustris $\mathrm{E} 1-9 \mathrm{c}^{\mathrm{T}}$ ) are in the range $92.8-96.3 \%$, which are comparable to those among the species of the family Methanomicrobiaceae (89.3-95.1\%), another family within the order Methanomicrobiales (Fig. 2). We therefore propose the status of family for the E1/E2 group and propose the name Methanoregulaceae fam. nov., with Methanoregula as the type genus (type species Methanoregula boonei) of the new family, because Methanoregula boonei $6 \mathrm{~A} 8^{\mathrm{T}}$ was the first isolate of the E1/E2 lineage (Bräuer et al., 2006a).

\section{Description of Methanoregulaceae fam. nov.}

Methanoregulaceae (Me.tha.no.re.gu.la'ce.ae N.L. fem. n. Methanoregula type genus of the family; suff. -aceae ending to donate a family; N.L. fem. pl. n. Methanoregulaceae the Methanoregula family).

Cells are rod-shaped or coccoid. Use $\mathrm{H}_{2} / \mathrm{CO}_{2}$ and sometimes formate for growth and methane production. Acetate is required for growth. Some strains also require yeast extract and coenzyme $\mathrm{M}$ for growth. The family belongs to the order Methanomicrobiales. The type genus is Methanoregula.

\section{Description of Methanolinea mesophila sp. nov.}

Methanolinea mesophila (me.so'phi.la. Gr. adj. mesos medium; Gr. adj. philos loving; N.L. fem. adj. mesophila medium-temperature-loving, mesophilic).

Cells are non-motile, rod-shaped, $0.3 \mu \mathrm{m}$ wide and 2.0$6.5 \mu \mathrm{m}$ long. Multicellular filamentous (up to around $100 \mu \mathrm{m}$ ) and coccoid (about $1 \mu \mathrm{m}$ in diameter) cells are also observed, especially in the late-exponential phase cultures. $\mathrm{H}_{2} / \mathrm{CO}_{2}$ and formate can be used for growth and methane production. Acetate is required for growth. Yeast extract and coenzyme $\mathrm{M}$ enhance growth. Growth occurs at $20-40{ }^{\circ} \mathrm{C}$ (optimum at $37^{\circ} \mathrm{C}$ ), at $\mathrm{pH}$ 6.5-7.4 (optimum pH 7.0) and in the presence of $\mathrm{NaCl}$ concentrations below $25 \mathrm{~g} \mathrm{l}^{-1}$. Cultures are resistant to ampicillin, kanamycin, streptomycin and vancomycin at a concentration of $100 \mu \mathrm{g} \mathrm{ml}^{-1}$.

The type strain, $\mathrm{TNR}^{\mathrm{T}}\left(=\mathrm{NBRC} 105659^{\mathrm{T}}=\mathrm{DSM} 23604^{\mathrm{T}}\right)$, was isolated from rice field soil in Tainan, Taiwan. The DNA G + C content of the type strain is $56.4 \mathrm{~mol} \%$.

\section{Acknowledgements}

We thank Eiji Tasumi and Masayuki Miyazaki at JAMSTEC for their technical assistance. This study was partly supported by grants from the Japan Society for the Promotion of Science, the Ministry of Education, Culture, Sports, Science and Technology, Japan, and the Institute for Fermentation, Osaka, Japan.

\section{References}

Bräuer, S. L., Cadillo-Quiroz, H., Yashiro, E., Yavitt, J. B. \& Zinder, S. H. (2006a). Isolation of a novel acidiphilic methanogen from an acidic peat bog. Nature 442, 192-194. 
Bräuer, S. L., Yashiro, E., Ueno, N. G., Yavitt, J. B. \& Zinder, S. H. (2006b). Characterization of acid-tolerant $\mathrm{H}_{2} / \mathrm{CO}_{2}$-utilizing methanogenic enrichment cultures from an acidic peat bog in New York State. FEMS Microbiol Ecol 57, 206-216.

Bräuer, S. L., Cadillo-Quiroz, H., Ward, R. J., Yavitt, J. B. \& Zinder, S. H. (2011). Methanoregula boonei gen. nov., sp. nov., an acidiphilic methanogen isolated from an acidic peat bog. Int J Syst Evol Microbiol 61, 45-52.

Cadillo-Quiroz, H., Bräuer, S., Yashiro, E., Sun, C., Yavitt, J. \& Zinder, S. (2006). Vertical profiles of methanogenesis and methanogens in two contrasting acidic peatlands in central New York State, USA. Environ Microbiol 8, 1428-1440.

Cadillo-Quiroz, H., Yashiro, E., Yavitt, J. B. \& Zinder, S. H. (2008). Characterization of the archaeal community in a minerotrophic fen and terminal restriction fragment length polymorphism-directed isolation of a novel hydrogenotrophic methanogen. Appl Environ Microbiol 74, 2059-2068.

Cadillo-Quiroz, H., Yavitt, J. B. \& Zinder, S. H. (2009). Methanosphaerula palustris gen. nov., sp. nov., a hydrogenotrophic methanogen isolated from a minerotrophic fen peatland. Int J Syst Evol Microbiol 59, 928-935.

Chen, C.-L., Macarie, H., Ramirez, I., Olmos, A., Ong, S. L., Monroy, O. \& Liu, W.-T. (2004). Microbial community structure in a thermophilic anaerobic hybrid reactor degrading terephthalate. Microbiology 150, 3429-3440.

Chen, C.-L., Wu, J.-H., Tseng, I.-C., Liang, T.-M. \& Liu, W.-T. (2009). Characterization of active microbes in a full-scale anaerobic fluidized bed reactor treating phenolic wastewater. Microbes Environ 24, 144153.

Díaz, E. E., Stams, A. J. M., Amils, R. \& Sanz, J. L. (2006). Phenotypic properties and microbial diversity of methanogenic granules from a full-scale upflow anaerobic sludge bed reactor treating brewery wastewater. Appl Environ Microbiol 72, 4942-4949.

Felsenstein, J. (1985). Confidence limits of phylogenies: an approach using the bootstrap. Evolution 39, 783-791.

Ferry, J. G., Smith, P. H. \& Wolfe, R. S. (1974). Methanospirillum, a new genus of methanogenic bacteria, and characterization of Methanospirillum hungatei sp. nov. Int J Syst Bacteriol 24, 465-469.

Galand, P. E., Saarnio, S., Fritze, H. \& Yrjälä, K. (2002). Depth related diversity of methanogen Archaea in Finnish oligotrophic fen. FEMS Microbiol Ecol 42, 441-449.

Hales, B. A., Edwards, C., Ritchie, D. A., Hall, G., Pickup, R. W. \& Saunders, J. R. (1996). Isolation and identification of methanogenspecific DNA from blanket bog peat by PCR amplification and sequence analysis. Appl Environ Microbiol 62, 668-675.

Imachi, H., Sekiguchi, Y., Kamagata, Y., Loy, A., Qiu, Y.-L., Hugenholtz, P., Kimura, N., Wagner, M., Ohashi, A. \& Harada, H. (2006). Non-sulfate-reducing, syntrophic bacteria affiliated with desulfotomaculum cluster I are widely distributed in methanogenic environments. Appl Environ Microbiol 72, 2080-2091.

Imachi, H., Sakai, S., Sekiguchi, Y., Hanada, S., Kamagata, Y., Ohashi, A. \& Harada, H. (2008). Methanolinea tarda gen. nov., sp. nov., a methane-producing archaeon isolated from a methanogenic digester sludge. Int J Syst Evol Microbiol 58, 294-301.

Imachi, H., Sakai, S., Nagai, H., Yamaguchi, T. \& Takai, K. (2009). Methanofollis ethanolicus sp. nov., an ethanol-utilizing methanogen isolated from a lotus field. Int J Syst Evol Microbiol 59, 800-805.

Keswani, J. \& Whitman, W. B. (2001). Relationship of $16 \mathrm{~S}$ rRNA sequence similarity to DNA hybridization in prokaryotes. Int J Syst Evol Microbiol 51, 667-678.

Ludwig, W., Strunk, O., Westram, R., Richter, L., Meier, H., Yadhukumar, Buchner, A., Lai, T., Steppi, S. \& other authors (2004). ARB: a software environment for sequence data. Nucleic Acids Res 32, 1363-1371.
Lykidis, A., Chen, C.-L., Tringe, S. G., McHardy, A. C., Copeland, A., Kyrpides, N. C., Hugenholtz, P., Macarie, H., Olmos, A. \& other authors (2011). Multiple syntrophic interactions in a terephthalatedegrading methanogenic consortium. ISME J 5, 122-130.

Nakagawa, S., Takai, K., Horikoshi, K. \& Sako, Y. (2003). Persephonella hydrogeniphila sp. nov., a novel thermophilic, hydrogen-oxidizing bacterium from a deep-sea hydrothermal vent chimney. Int J Syst Evol Microbiol 53, 863-869.

Narihiro, T., Terada, T., Ohashi, A., Wu, J.-H., Liu, W.-T., Araki, N., Kamagata, Y., Nakamura, K. \& Sekiguchi, Y. (2009). Quantitative detection of culturable methanogenic archaea abundance in anaerobic treatment systems using the sequence-specific rRNA cleavage method. ISME J 3, 522-535.

Ollivier, B. M., Mah, R. A., Garcia, J. L. \& Boone, D. R. (1986). Isolation and characterization of Methanogenium bourgense sp. nov. Int J Syst Bacteriol 36, 297-301.

Ollivier, B., Fardeau, M.-L., Cayol, J.-L., Magot, M., Patel, B. K. C., Prensier, G. \& Garcia, J.-L. (1998). Methanocalculus halotolerans gen. nov., sp. nov., isolated from an oil-producing well. Int J Syst Bacteriol 48, 821-828.

Paynter, M. J. B. \& Hungate, R. E. (1968). Characterization of Methanobacterium mobilis, sp. n., isolated from the bovine rumen. J Bacteriol 95, 1943-1951.

Rivard, C. J., Henson, J. M., Thomas, M. V. \& Smith, P. H. (1983). Isolation and characterization of Methanomicrobium paynteri sp. nov., a mesophilic methanogen isolated from marine sediments. Appl Environ Microbiol 46, 484-490.

Romesser, J. A., Wolfe, R. S., Mayer, F., Spiess, E. \& WaltherMauruschat, A. (1979). Methanogenium, a new genus of marine methanogenic bacteria, and characterization of Methanogenium cariaci sp. nov. and Methanogenium marisnigri sp. nov. Arch Mikrobiol 121, 147-153.

Sakai, S., Imachi, H., Sekiguchi, Y., Ohashi, A., Harada, H. \& Kamagata, Y. (2007). Isolation of key methanogens for global methane emission from rice paddy fields: a novel isolate affiliated with the clone cluster rice cluster I. Appl Environ Microbiol 73, 4326-4331.

Sakai, S., Imachi, H., Hanada, S., Ohashi, A., Harada, H. \& Kamagata, Y. (2008). Methanocella paludicola gen. nov., sp. nov., a methane-producing archaeon, the first isolate of the lineage 'Rice Cluster I', and proposal of the new archaeal order Methanocellales ord. nov. Int J Syst Evol Microbiol 58, 929-936.

Sakai, S., Imachi, H., Sekiguchi, Y., Tseng, I.-C., Ohashi, A., Harada, H. \& Kamagata, Y. (2009). Cultivation of methanogens under lowhydrogen conditions by using the coculture method. Appl Environ Microbiol 75, 4892-4896.

Stackebrandt, E. \& Goebel, B. M. (1994). Taxonomic note: a place for DNA-DNA reassociation and $16 \mathrm{~S}$ rRNA sequence analysis in the present species definition in bacteriology. Int J Syst Bacteriol 44, 846-849.

Tamura, K., Peterson, D., Peterson, N., Stecher, G., Nei, M. \& Kumar, S. (2011). MEGA5: molecular evolutionary genetics analysis using maximum likelihood, evolutionary distance, and maximum parsimony methods. Mol Biol Evol 28, 2731-2739.

Wildgruber, G., Thomm, M., König, H., Ober, K., Ricchiuto, T. \& Stetter, K. O. (1982). Methanoplanus limicola, a plate-shaped methanogen representing a novel family, the Methanoplanaceae. Arch Microbiol 132, 31-36. Yashiro, Y., Sakai, S., Ehara, M., Miyazaki, M., Yamaguchi, T. \& Imachi, H. (2011). Methanoregula formicica sp. nov., a methaneproducing archaeon isolated from methanogenic sludge. Int J Syst Evol Microbiol 61, 53-59.

Ye, W., Liu, X., Lin, S., Tan, J., Pan, J., Li, D. \& Yang, H. (2009). The vertical distribution of bacterial and archaeal communities in the water and sediment of Lake Taihu. FEMS Microbiol Ecol 70, 107120 . 
Zabel, H. P., König, H. \& Winter, J. (1984). Isolation and characterization of a new coccoid methanogen, Methanogenium tatii spec. nov. from a solfataric field on Mount Tatio. Arch Microbiol 137, 308315.
Zellner, G., Alten, C., Stackebrandt, E., Conway de Macario, E. \& Winter, J. (1987). Isolation and characterization of Methanocorpusculum parvum gen. nov., spec. nov., a new tungsten requiring, coccoid methanogen. Arch Microbiol 147, 13-20. 